\title{
Exploring Linkage Among Experiential Value, Image of Destination, and Intention to Revisit in Nature Tourism
}

\author{
Heri Setiawan $^{1 *}$, Muchsin Sagaf Shihab ${ }^{2}$, Taufiq Marwa ${ }^{2}$, Zakaria Wahab $^{2}$
}

\author{
${ }^{1}$ Student Doctoral of Management Science, Universitas Sriwijaya, Palembang, Indonesia \\ ${ }^{2}$ Lecturer of Economic Faculty, Universitas Sriwijaya, Palembang, Indonesia \\ *Corresponding author. Email: heri.setiawan@polsri.ac.id
}

\begin{abstract}
Natural based tourism is one of the tourist activities offered by tourism destination managers and it is increasingly in demand by tourists. The study of tourist visits to natural tourism destinations is still limited. Exploration of experiential value, image of destination and intention to revisit natural tourism destinations is examined in this study. The samples in this study were 180 respondents with the purposive sampling technique used. The research sample was domestic tourists who had visited natural tourism destinations in Palembang during May 2019. Data collected through questionnaires to respondents and further processed using SPSS 23 and AMOS 22 to determine the minimum requirements and hypotheses testing. Results of analysis explain the value of experience has a significant and positive effect on the image of tourism destination. Experiential value of tourist has a significant and positive effect on the intention to revisit. However, the image of tourism destination has not a significant and positive effect on the intention to revisit. Therefore, results of the study can provide an understanding of visiting intentions and can be a basis for destination managers and related parties to pay attention to marketing natural tourism destinations.
\end{abstract}

Keywords: experiential value, destination image, revisit intention, natural tourism

\section{INTRODUCTION}

The increase of tourist arrivals to various tourism destinations has increasingly encouraged managers of tourism destinations to develop and offer relatively different tourism attractions from other destinations. The attractiveness of destinations is the crucial capital that must be owned to improve and develop these tourism destinations and attractions. The existence of tourism destinations and attractions is the most important link in tourist activities. This is because the main factor to make tourists to visit tourism destinations is the potential and attractiveness of these tourism destinations. The interest of domestic and foreign tourists to visit tourism destinations related to nature has increased and become a tourist attraction for tourists.

Natural based tourism becomes attractive for tourists to visit because of its uniqueness and authenticity that is not owned by other tourism destinations. Destination image relates to the intention to revisit the rural tourism in North Caroline [1]. The uniqueness and attractiveness of the image of natural tourism destinations will encourage tourists to visit these destinations and recommend to other parties and will give a deep impression to tourists.
Tourist experience is one of the important things in tourism activities because tourists will be able to fulfill holiday needs by visiting a tourism destination [2]. Based on the business perspective in the tourism sector, the most important thing that concerns tourism managers is whether visits and tourist experiences have an impact on tourist behavior in the future, either through revisiting or giving recommendations to tourism destinations to other parties. Tourists who have impressive experiences in a tourism destination tend to give a good assessment of the destination and will intend to revisit and provide recommendations to other parties to visit tourism destinations.

Studies of the interrelationship between consumer experiential values and various other factors have been studied in various fields such as retail business [3], [4], museums [5], festivals and events [6],[7], restaurants [8], [9], [10], accommodation [11], [12], cruise ship tours [13], health tourism [14], culinary tourism [15]. However, interrelation amongst experiential value of tourist, destination image and intention to revisit to nature tourism destinations has not been widely studied by researchers. Therefore, this study tried to cover the research gap relating to the experiential value of tourist, image of destination and intention to revisit to nature tourism destinations. 


\section{LITERATURE HYPOTHESES}

REVIEW

AND

\subsection{Experiential Value}

Value of experiential is expressed as a consumer's assessment of the use of a product or service either directly or through indirect observation [3]. Studies relating to consumption activities as consumer experience have attracted various studies conducted by experts [16], [17], [18]. The consumer experiential value in consuming a product or service is determined by various component like environment, goods, and services value [19], and consumer perceptions of what is produced and offered by a company [20]. [21] study which investigated the tourist experience in enjoying grape-processed tourism states that the value of experiential is the preceding of satisfaction and loyalty of tourist. The experience of tourists influences the intention of revisiting creative destinations of tourism [22].

\subsection{Destination Image}

Image of destination is the impression and perception of tourists about a place or location [23]. Image of destination comprise of serviceable characteristics that involve real facet of psychological and nature regarding the nonphysical aspects. Image of destination could be composed in a sequence of uniqueness of destination characteristics. Destination image is a picture, though, trust, feeling and perception of a destination [24]. Tourism destinations consist of a set of related attributes that are an inseparable and unique part of the tourist experience of visiting the destination. The destination image consists of functional characteristics that focus on physical evidence aspect of a destination and psychological characteristics that focus on nonphysical evidence aspect [25].

\subsection{Intention to Revisit}

Decision to return to destination of tourism seems to be a complex decision that involves many interrelated factors such as satisfaction after visiting, tourist motivation, prior experience of a tourist destination. Revisit Intention a factor that determines individual behavior in carrying out trips in the future [26]. Revisit intention is a tourist activity to participate again in a tourist activity [27]. Travel behavior carried out by tourists is a result of various factors [28]. Revisit intention is defined as an interest in repurchase (purchase intention), which is a strong desire to repurchase [29].

\subsection{Experiential Value and Destination Image}

Value of experiential perceived by customers can lead to customer satisfaction [30]. Value of experiential dimensions positively influence customer behavior intention [4]. Value of tourist experience does not significantly influence the image of culinary destinations, while the image of culinary destination has a significant effect on intention [15]. Then, the value of experience significantly influence to image of the restaurant, which means that pleasant consumer experience will shape the perception of restaurant images in the consumer's mind [8].

H1: Experiential value significantly influence to destination images.

\subsection{Experiential value and intention to revisit}

Value of experiential significantly influence the behavior intentions of customer [4]. Active experiences during visiting museums will encourage intention of tourist to participate sharing of information to others and revisit [5]. The value of experiential besides describing satisfaction of internal visitor perception with the visit activities to tourism destinations can also measure the revisit intention effectively [31]. Tourists' recreational experiences relate to their revisit intention to the City of Tahu in Maioli [32]. Value of experiential significantly influences to revisit intention to Maqaw National Park [33].

$\mathrm{H} 2$ : Experiential value significantly influence to intention to revisit

\subsection{Destination image and intention to revisit}

Image of tourism destination determines the fundamental role in destination of tourism success. Crucial factors that encourage tourist satisfaction and visit intention to tourism destination is the perception of tourists about the image of the destination and the ability of the destination manager to provide an unforgettable experience for tourists [34]. Corporate image significantly influences to behave intention [35]. Image of destination image significantly influences to intention to revisit of rural tourism [1]. Image of destination is fundamental factors that encourage tourists to determine destination of tourism to revisit [36], [37], [15].

H3: Destination image significantly influence to intention to revisit

\section{METHODS}

\subsection{Design of Instrument Research}

Explanatory/confirmatory research as design of research is used to analyze the interrelation among the value of 
experiential, destination image and intention to revisit. The study intends to specify the causality association between research variables with hypothesis testing. The questionnaire was designed based on empirical studies used to measure constructs and measurement of construct items using a Likert scale of 1 to 5 . 5 indicators adapted from [15] are used to measure experience values. 5 indicators adapted from [36] are used to measure destination image. 3 indicators adapted from [36] are used to measure revisit intention.

\subsection{Population and Samples}

Domestic tourists who have visited various natural tourism destinations in Palembang were selected as the population of study. The research samples were 180 respondents with the selection provisions of domestic tourists in Palembang with certain considerations. survey method with questionnaire design used as research data collection approach [38]. Non-probability sampling method with purposive sampling was used in this study. This method was a sampling procedure that selected samples from individuals who had visited natural tourism destinations in Palembang.

\subsection{Data Analysis}

The instrument validity test used confirmatory factor analysis and the indicator is said to be valid if the factor loading of value all indicators above 0.5 [39]. Finding the reliability of valid indicators using construct reliability with the help of excel programs and indicators is reliable if the value of construct reliability all latent variables are above 0.7 [39]. Analysis of research data using SEM analysis. Research hypothesis test was conducted by finding the significance of the causality relationship between variables.

\section{RESULTS}

\subsection{Validity and reliability of construct}

The value of $\alpha$ Cronbach and the reliability of Composite values are used to measure reliability. Value of $\alpha$ Cronbach for experiential value construct destination image and intention to revisit indicated have internal consistency significantly, from $0.796,0.839$ to 0.899 . Composite reliability (CR) values for experiential values construct, destination images and revisit intention ranged from 0.886 to 0.898 . This result explained that the research instrument used had good reliability because it was above the required value, which was 0.70 for $\alpha$ Cronbach and 0.60 for reliability of Composite [40].

All of the measurement model quality is examined using confirmatory factor analysis, including testing of convergent validity and discriminant validity. Results of the Convergent validity measurement model assisted by reliability of item, reliability of construct dan AVE [40]. The reliability of items showed the number of variance in the item of the construct, and the t-value related to every standard loading was significant ( $\mathrm{p}<0.01)$, indicating items were reliable. Construct reliability estimation have to equal to or greater than 0.7 and extraction of variance on average, the size of the variant numbers described by the construct must be above 0.5 [40].

Table 1 Result of reliability test

\begin{tabular}{|c|c|c|}
\hline Variables & Cronbach $\boldsymbol{\alpha}$ & $\begin{array}{c}\text { Reliability } \\
\text { of } \\
\text { Composite }\end{array}$ \\
\hline Experiential value & .796 & .923 \\
\hline Destination image & .839 & .830 \\
\hline Revisit intention & .899 & .994 \\
\hline
\end{tabular}

Table 2 Result of Convergent Validity Test

\begin{tabular}{|c|c|c|c|c|}
\hline Construct & $\begin{array}{c}\text { Standardiz } \\
\text { ed } \\
\text { regression }\end{array}$ & $\begin{array}{c}\text { Error } \\
\text { of } \\
\text { estimat } \\
\mathbf{e}\end{array}$ & t value & AVE \\
\hline & .623 & .117 & 5.342 & \\
Experien & .765 & .097 & 7.884 & \\
tial & .844 & .091 & 9.275 & .712 \\
Value & .990 & .093 & 10.25 & \\
\hline Destinati & .529 & .193 & - & \\
on Image & .929 & .224 & 7.005 & \\
& .590 & .144 & 3.441 & \\
& .664 & .208 & 7.988 & \\
\hline Revisit & .996 & .077 & - & \\
Intention & .988 & .070 & 14.288 & .584 \\
s & & .069 & 14.591 & \\
\hline
\end{tabular}

Table 3 Result of Discriminant Validity

\begin{tabular}{|c|c|c|c|}
\hline AVE/R2 & $\begin{array}{c}\text { Experienti } \\
\text { al Value }\end{array}$ & $\begin{array}{c}\text { Destinatio } \\
\text { n Image }\end{array}$ & $\begin{array}{c}\text { Revisit } \\
\text { Intentio } \\
\mathbf{n}\end{array}$ \\
\hline $\begin{array}{c}\text { Experiential } \\
\text { Value }\end{array}$ & $\mathbf{. 7 1 2}$ & & \\
\hline $\begin{array}{c}\text { Destination } \\
\text { Image }\end{array}$ & .412 & $\mathbf{. 6 3 1}$ & \\
\hline $\begin{array}{c}\text { Revisit } \\
\text { Intention }\end{array}$ & .454 & .490 & $\mathbf{. 5 8 4}$ \\
\hline
\end{tabular}

In this study, the reliability of constructs exceeded the accepted level and average variance extraction from the experiential value, destination image and revisit intention was more than 0.5. Results showed that the item of measurement has good validity and reliability. After 
calculating the convergent validity, the next stage calculated the discriminant validity to find out the occurrence of discrimination between constructs.

\subsection{Structural model and hypotheses testing}

Maximum likelihood estimation method is used to assess the quality of relationships between constructs in the conceptual model. Results of the overall measurement of the fit model index, obtained chi-square values with a sample of 180 respondents $=3.522$ with p-value $0.480(\alpha>$ $0.05), \mathrm{cmin} / \mathrm{df}=0.996$, so it could be concluded that the model is goodness of fit. Then, goodness of fit indicators have a good fit of model (RMSEA $=.000$, GFI $=.962$, $\mathrm{AGFI}=.927, \mathrm{TLI}=1.000, \mathrm{CFI}=1.000)$. Significance level of the research hypothesis can be determined using a critical ratio (C.R) [41].

Based on Table 4, the relationship between experiential value and destination image was positive and significant $(\beta$ $=0.289$, C.R $=4,436$ ) so that it supported hypothesis 1 . The relationship between experience value and intention to revisit was positive and significant $(\beta=0.683, \mathrm{CR}=$ 7,232 ), thus supporting the hypothesis 2 . Then, the relationship between destination image and intention to revisit was positive and not significant $(\beta=0.132, \mathrm{CR}=$ 1203), thus rejecting hypothesis 3 .

This study examined and analyzed the interrelation between experiential value, image of destination and intention to revisit. Experience value is positively and significantly related to the destination image. The results of the study support [30], [8] states that the value of experience has a positive and significant linear relationship with the image of the destination.

Table 4 Result of Structural Equation Model

\begin{tabular}{|l|c|c|c|c|}
\hline \multicolumn{1}{|c|}{$\begin{array}{c}\text { Testing of } \\
\text { Hypotheses }\end{array}$} & $\begin{array}{c}\text { Path } \\
\text { estimat } \\
\text { e }\end{array}$ & $\begin{array}{c}\text { Critica } \\
\text { I Ratio }\end{array}$ & $\begin{array}{c}\text { P } \\
\text { value }\end{array}$ & $\begin{array}{c}\text { Cri } \\
\text { teri } \\
\text { a }\end{array}$ \\
\hline $\begin{array}{l}\text { Experiential } \\
\text { value } \\
\rightarrow \text { Destination } \\
\text { Image }\end{array}$ & .289 & 4.436 & .000 & $\mathrm{~S}$ \\
\hline $\begin{array}{l}\text { Experiential } \\
\text { value } \rightarrow \text { Revisit } \\
\text { Intention }\end{array}$ & .683 & 7.232 & .000 & $\mathrm{~S}$ \\
\hline $\begin{array}{l}\text { Destination } \\
\text { Image } \rightarrow \text { Revisit } \\
\text { Intention }\end{array}$ & .132 & 1.203 & .229 & $\mathrm{NS}$ \\
\hline
\end{tabular}

Experience value is positively and significantly associated with intention to revisit. Result of the study supported the research of [5], [33], [32], [31] who emphasizes that experience value has a positive and significant relationship with revisit intention. The result provided a clear understanding that the experiential value was a factor that played a crucial function in enhancing intention to revisit.

Destination image is positively and not significantly associated with intention to revisit. The result of the study was different from the research of [42], [1], [36], [37] which states that the destination image significantly related with revisit intention. Then, the destination image had a role in influencing the revisit intention. Destination image was a description and perception of tourists towards a destination that could influence the tourist desire to visit a tourism destination.

\section{DISCUSSION}

The study results explained that experience value is positively and significantly related to the destination image. Tourists who visited natural tourism destinations provided relatively good assessments related to tourist experiences from the destinations they visit. Experience value is positively and significantly associated with intention to revisit. Tourists who had visited natural tourism destinations had a pleasant and memorable experience so they would intend to revisit the destination. Destination image is positively and not significantly associated with intention to revisit. It could be interpreted that respondents generally recognized the natural destination image relatively good, but most natural tourism destinations had not been well managed due to the lack of good supporting infrastructures and services so that it encourages tourists not to revisit. The results of the study can provide advice to manager natural tourism destinations must have considered improving services and providing good standard infrastructures so that tourists would feel comfortable and happy when they were or visited natural tourism destinations.

The study had various limitedness, foremost the study only used a small sample of 180 domestic tourists visiting natural tourism destinations in Palembang. Thus, the results of this study were not been able to represent the study of tourist visits to natural tourism as a whole. Therefore, relatively larger samples are needed to test models to get more accurate results and broad generalizations. Second, this study had not reviewed the rating of tourists about image of destination, value of experience and intention to revisit to natural tourism destinations as seen from tourist demographic factors, so that further research can include tourist demographic factors as research variables.

\section{REFERENCES}

[1] Phillips, W. J., Wolfe, K., Hodur, N., and Leistritz, F. L. (2011). Tourist Word of Mouth and Revisit Intentions to Rural Tourism Destinations: a Case of North Dakota, USA. International Journal of Tourism Research, 15(1), pp.93-104. 
[2] Prebensen, N, K., Woo, E., and Uysal, M. S. (2013). Experience value: antecedents and Consequences, Current Issues in Tourism, 17(10), pp. 1-19.

[3] Mathwick, C., Malhotra, N., and Rigdon, E. (2001). Experiential value: Conceptualization, measurement, and application in the catalog and internet shopping environment. Journal of Retailing, 77(1), pp.39-56.

[4] Keng, C. J., Huang, T. L., Zheng, L. J., and Hsu, M. K. (2007). Modeling Service Encounters and Customer Experiential Value in Retailing: An Empirical Investigation of Shopping Mall Customers in Taiwan," International Journal of Service Industry Management, 18(4), pp. 349-367.

[5] Anton, C., Camarero, C., and Jose Garrido, M. (2017). Exploring the experience value of museum visitors as a co-creation process, Current Issues in Tourism, 21(12), pp.1406-1425.

[6] Lee, W., Sung, H., Suh, E. and Zhao, J. (2017). The effects of festival attendees' experiential values and satisfaction on re-visit intention to the destination, International Journal of Contemporary Hospitality Management, 29(3), pp. 1005-1027.

[7] Lin, L.Z., Yeh, H.R. and Hsu, T.H. (2014). Multidimensions of experiential values in the Taipei International Flora expositions, Tourism Management Perspectives, 9, pp. 36-50.

[8] Chen, H. B., Yeh, S. S., and Huan, T. C. (2014). Nostalgic emotion, experiential value, brand image, and consumption intentions of customers of nostalgic-themed restaurants. Journal of Business Research, 67(3), pp. 354-360.

[9] Gunawan, A. (2014). Analisis perbandingan experiential value Antara hong tang dan black ball Serta hubungannya dengan customer satisfaction, Binus business review, 5(2), pp. 648-657.

[10] Jin, N., Line, N. D., and Goh, B. (2013). Experiential value, relationship quality, and customer loyalty in full-service restaurants: The moderating role of gender. Journal of Hospitality Marketing Management, 22(7), pp. 679-700.

[11]Cetin, G., Akova, O., and Kaya, F. (2014). Components of experiential value: Case of hospitality industry, Procedia-Social and Behavioral Sciences, 150, pp. 1040-1049
[12] Amoah, F., Radder, L., and van Eyk, M. (2016). Experience quality dimensions and customer perceptions: A case study of guesthouses in Ghana. African Journal of Hospitality, Tourism and Leisure, 5 (4), pp. 1-21.

[13] Wu, C.H., Cheng, C.C., and Ai, C.H. (2018). A study of experiential quality, experiential value, trust, corporate reputation, experiential satisfaction and behavioral intentions for cruise tourists: The case of Hong Kong. Tourism Management, 66, 200-220.

[14] Chen, Y. K., and Hsieh, T. (2010). A study of the relationship among experiential marketing, experiential value and customer satisfaction. Journal of Statistics \& Management Systems, 13(6), pp.1283-1303

[15] Tsai, C.T., and Wang, T.C. (2017). Experiential value in branding food tourism, Journal of Destination Marketing \& Management, 6, pp. 5665 .

[16] Hosany, S., and Withham, M. (2010). Dimensions of cruiser's experiences, satisfaction, and intention to recommend, Journal of Travel Research, 49(3), pp. 351-364

[17] Lee, J. S., Lee, C. K., and Choi, Y. (2011). Examining the role of emotional and functional values in festival evaluation. Journal of Travel Research, 50(6), pp.685-696.

[18] Gallarza, M. G., Gil Saura, I. and Arteaga M. F. (2013). The quality-value-satisfaction-loyalty chain: relationships and impacts, Tourism Review, 68(1), pp. 3-20.

[19] Lewis, R. C., and Chambers, R. E. (2000). Marketing leadership in hospitality. New York, NY: John Wiley

[20] Chen, P. T., and Hu, H. H. (2010). How determinant attributes of service quality influence customer perceived value: an empirical investigation of the Australian coffee outlet industry, International Journal of Contemporary Hospitality Management, 22(4), pp. 535-551.

[21] Lee, T. H., and Chang, Y. S. (2012). The influence of experiential marketing and activity involvement on the loyalty intentions of wine tourists in Taiwan, Leisure studies, 31(1), pp. 103-121. 
[22] Chang, L., Backman, K. F., and Huang, Y. C. (2014). Creative tourism: a preliminary examination of creative tourists' motivation, experience, perceived value and revisit intention, International Journal of Culture, Tourism and Hospitality Research, 8(4), pp. 401-419.

[23] Gallarza, M. G., Saura, I. G., and García, H. C. (2002). Destination image. Annals of Tourism Research, 29(1), pp. 56-78.

[24] Choshall, J.T. (2002). Measurement of Tourists Images: The Repertory Grid Approach, Journal Travel Research, 39(1), pp. 85-89

[25]Echtner, C. M., and Ritchie, J.R.B. (2003). The Meaning and Measurement of Tourism Destination Image, The Journal of Tourism Studies, 14(1), pp. $37-48$.

[26] Lee, T. H. (2009). A structural model to examine how destination image, attitude, and motivation affect the future behavior of tourists. Leisure Sciences: An Interdisciplinary Journal, 31(3), pp. 215-236.

[27]Baker, D., and Crompton, J. (2000). Quality, satisfaction, and behavioral intentions. Annals of Tourism Research, 27(3), pp.785-804.

[28] Luo, S.J., and Hsieh, L.Y. (2013). Reconstructing Revisit Intention Scale in Tourism, Journal of Applied Science, 13(18), pp. 3638-3648.

[29] Fullerton, G., and Shirley, T. (2000). The Role of Commitment in Service Relationship, Kingston, Ontario: School of Business Acadia University, limited publication. pp. 83-97.

[30] Datta, V., and Vasantha, S. (2013). Experiential value, customer satisfaction, and customer loyalty: an empirical study of KFC in Chennai. Indian Journal of Applied Research, 3(9), pp.334-337.

[31] Samdin, Z., Aziz, Y. A., Radam, A., and Yacob, M. R. (2013): Sustainability Of Ecotourism Resources At Taman Negara National Park: Contingent Valuation Method. International Journal of Business and Society, 14, pp. 235-244.

[32] Zsóka, Á., Szerényi, Zs. M., Széchy, A., and Kocsis, T. (2013). Greening due to environmental education? Environmental knowledge, attitudes, consumer behavior and everyday proenvironmental activities of Hungarian high school and university students. Journal of Cleaner Production 48, pp. 126-138.

[33] Chien, M.C. (2017). An empirical study on the effect of attractiveness of ecotourism destination on experiential value and revisit intention, Applied Ecology, and Environmental Research, 15(2): pp. 43-53

[34] Beerli, A., and Martin, J. D. (2004). Factors influencing destination image. Annals of Tourism Research, 31(3), pp. 657-681

[35] Wu, C.H. (2013). An Empirical Study of the Effects of Service Quality, Perceived Value, Corporate Image, and Customer Satisfaction on Behavioral Intentions in the Taiwan Quick Service Restaurant Industry, Journal of Quality Assurance in Hospitality \& Tourism, 14(4), pp. 364-390

[36] Jalilvand, M. R., Samiei, N., Dini, B., and Manzari, P.Y. (2012). Examining the structural relationships of electronic word of mouth, destination image, tourist attitude toward destination and travel intention: An integrated approach, Journal of Destination Marketing \& Management. 1(1/2), pp. 134-143.

[37] Allameh, S., Khazaei Pool, J., Jaberi, A., Salehzadeh, R. and Asadi, H. (2015). Factors influencing sport tourists' revisit intentions, Asia Pacific Journal of Marketing and Logistics, 27(2), pp. 191-207.

[38] Malhotra, N., and Dash, S. (2011). Marketing research An applied orientation (6th ed.). Dorling Kindersley (India) Pvt, Ltd., Licensees of Pearson Education in South Asia.

[39] Hair, J. F., Black. W. C., Babin. B. J., and Anderson. R. E. (2010), Multivariate Data Analysis, 7th ed. Pearson Prentice Hall, New Jersey.

[40] Hair Jr, J.F., Hult, G.T.M., Ringle, C.M and Sarstedt, M. (2016). A Primer on Partial Least Squares Structural Equation Modeling (PLS-SEM) (Second Edi). Los Angeles: SAGE Publications, Inc.

[41]Hair et al., (1998), Multivariate Data Analysis, Fifth Edition, Prentice Hall, Upper Saddle River : New Jersey.

[42] Choi, J.G., Tkachenko, T., and Sil, S. (2011). On the destination image of Korea by Russian tourists. Tourism Management, 32: pp. 193-194. 